\title{
REVISION OF THE DEVONIAN FENESTRATE BRYOZOAN GENERA Cyclopelta BORNEMANN, 1884 AND Pseudoisotrypa PRANTL, 1932, WITH DESCRIPTION OF A RARE FENESTRATE GROWTH HABIT
}

\author{
Juan Luis SUÁREZ-ANDRÉS $S^{l}$ and Frank K. \\ MCKINNEY² \\ ${ }^{1}$ B ${ }^{\circ}$ El Bardal 33A, 1A, 39479 Zurita de Piélagos, Cantabria, Spain. \\ juanl_suarez@yahoo.es \\ ${ }^{2}$ Department of Geology, Appalachian State University. Boone, NC 28608, USA. \\ mckinneyfk@appstate.edu
}

Suárez-Andrés, J. L. \& McKinney, F. K. 2010. Revision of the Devonian fenestrate bryozoan genera Cyclopelta Bornemann, 1884 and Pseudoisotrypa Prantl, 1932, with description of a rare fenestrate growth habit. [Revisión de los géneros de briozoos fenestrados devónicos Cyclopelta Bornemann, 1884 y Pseudoisotrypa Prantl, 1932, con descripción de un raro hábito de crecimiento fenestrado.] Revista Española de Paleontología, 25 (2), 123 138. ISSN 0213-6937.

\begin{abstract}
The fenestrate bryozoan genus Cyclopelta is common and locally abundant in Devonian rocks of central and western Europe. Cyclopelta is a junior homonym and is here renamed Bigeyina. The Bohemian genus Pseudoisotrypa, very closely related with Bigeyina and formerly interpreted as a junior synonym of the latter, is restored herein as a valid taxon. Revised diagnoses of both genera and their type species are provided. Also, an extremely rare variation on the conical growth habit is reported in Bigeyina and implies higher plasticity in this genus than usual in fenestrates. The presence of abundant Bigeyina zoaria with this rare growth habit in the well known outcrop of Arnao (Spain), emphasizes the need for the preservation of its paleontological heritage.
\end{abstract}

Keywords: Semicosciniidae, Taxonomy, homonymy, Lower-Middle Devonian, branching zoarium, Arnao (Spain), Prague Basin (Czech Republic), Eifel (Germany).

\section{RESUMEN}

El género de briozoos fenestrados Cyclopelta es común y localmente abundante en el Devónico de Europa central y occidental. Cyclopelta es un homónimo y se le asigna el nuevo nombre Bigeyina. El género bohémico Pseudoisotrypa, estrechamente relacionado con Bigeyina y previamente interpretado como un sinónimo del mismo, se restaura como taxón válido. Se aportan las diagnosis revisadas de ambos géneros y de sus especies tipo. También se describe una variante del hábito de crecimiento cónico extremadamente rara y observada en Bigeyina, que implica una plasticidad superior en este género a la habitual en los fenestrados. La presencia de abundantes zoarios de Bigeyina con este peculiar hábito de crecimiento en el yacimiento de Arnao (España), se suma a su ya conocido patrimonio paleontológico, reforzando la necesidad de su protección.

Palabras clave: Semicosciniidae, Taxonomía, homonimia, Devónico Inferior-Medio, zoario ramificado, Arnao (España), Cuenca de Praga (República Checa), Eifel (Alemania).

\section{INTRODUCTION}

The Devonian fenestrate bryozoan genus Cyclopelta was originally defined by Bornemann (1884) from the Eifel, Germany for a single species, $C$. winteri. The species and genus were not reported again in the literature until
1953. Kräusel (1953) collected additional material from the type locality and designated a neotype for the type species, C. winteri, because Bornemann's original type material of Cyclopelta is lost. In his 1953 paper Kräusel provided an improved, thorough description of Cyclopelta and its morphological variability, including characters 
such as the termination of the keels, supported by plate figures and line drawings. Later Kräusel (1954) described a second species of Cyclopelta, which he initially designated as Cyclopelta sp. A and later named formally as $C$. concentrica Kräusel, 1956.

Almost a half century after Bornemann used the name Cyclopelta for a bryozoan, Prantl (1932) named the new genus Pseudoisotrypa in a description of the Devonian fenestrate fauna of the Prague Basin, in which he included two new species, $P$. bohemica and $P$. cancellata. He did not report the presence of Cyclopelta in the rich Bohemian fauna. No further reports of Pseudoisotrypa were recorded following the publication of Prantl's (1932) work.

In the Treatise on invertebrate paleontology, Bassler (1953) considered Pseudoisotrypa Prantl, 1932 to be a recognizable genus but questionably synonymized Cyclopelta Bornemann, 1884 with Semicoscinium Prout, 1859. In Osnovy paleontologii, Shulga-Nesterenko et al. (1960) did not include Cyclopelta but placed Pseudoisotrypa in synonymy with Loculipora Hall, 1885. McKinney \& Kř́žz (1986) revised the Bohemian fenestellids and emended many of Prantl's identifications. The genus Pseudoisotrypa was considered to be a junior synonym of Cyclopelta Bornemann, 1884; they transferred the species $P$. bohemica to $C$. bohemica, and the original material of $P$. cancellata was distributed into $C$. bohemica and three species of Isotrypa.

More recently, Suárez (1997, 1998a, b) cited and described Cyclopelta from the Devonian of NW Spain. These references represent the southernmost occurrence of this genus reported to date. Dealing with a preliminary bryozoan fauna inventory in the classical Lower Devonian Arnao outcrop in 2009, the authors became aware that $C y$ clopelta Bornemann, 1884 is a junior homonym, preoccupied by the insect Cyclopelta Amyot \& Serville, 1843. Thus, if McKinney \& Kř́ž (1986) were correct that Pseudoisotrypa Prantl, 1932 is a junior subjective synonym of Cyclopelta Bornemann, 1884 (non Amyot \& Serville, 1843), bryozoan species previously considered to be $C y$ clopelta must be transferred to Pseudoisotrypa.

We have re-evaluated type and other material of $C y$ clopelta winteri Bornemann, 1884 and of Pseudoisotrypa bohemica Prantl, 1932 and judge them not to be congeneric with one another nor with Semicoscinium or Loculipora Hall, 1885. In this paper we compare the characteristics of the two type species that we infer to warrant retention in different genera, give diagnoses of their respective genera, and introduce the name Bigeyina to replace Cyclopelta Bornemann, 1884 (non Amyot \& Serville, 1843).

Also, zoaria of Bigeyina with a rare growth habit are described and figured herein for the first time. They consist of a variation on complexly pleated cone-shaped zoaria, which have been observed to be very common in Arnao, a well known Emsian outcrop in NW Spain that is currently being studied for the protection of its exceptional paleontological heritage.

\section{MATERIAL AND METHODS}

Photographs of the type specimens and additional material of Cyclopelta winteri Bornemann, 1884 and Pseudoisotrypa bohemica Prantl, 1932 have been studied for diagnosis and description of the genera and the type species themselves. Photographs and systematic descriptions of Bohemian species of Cyclopelta Bornemann, 1884 reported by McKinney \& Kř́ž (1986) have also been considered for the diagnosis of this genus. Types of Cyclopelta winteri are housed at the Senckenberg Museum, Frankfurt am Main, and additional material is housed both in the Senckenberg Museum and the University of Bonn. Types and additional material of Pseudoisotrypa bohemica are deposited in the National Museum (Natural History), Prague. Field photographs have been made of well preserved Bigeyina zoaria with the novel growth habit in the Emsian outcrop of Arnao Platform.

\section{TAXONOMIC PALEONTOLOGY}

\author{
Phylum BRYOZOA Ehrenberg, 1831 \\ Class STENOLAEMATA Borg, 1926 \\ Order FENESTRATA Elias \& Condra, 1957 \\ Family Semicosciniidae Morozova, 1987
}

\section{Genus Bigeyina nom. nov.}

(new name for Cyclopelta Bornemann, 1884 non Amyot \& Serville, 1843)

Type species: Cyclopelta winteri Bornemann, 1884

Derivatio nominis: In honor of Dr. Françoise P. Bigey, appreciated colleague and friend.

Diagnosis: Zoarium conical, narrow to broad and flaring; rarely a set of narrow branching, tubular cones. Autozooecial apertures on outer side of cone. Linear to sinuous, bifurcating branches, width intermediate to broad, spacing intermediate. Branches minimally to moderately sinuous, linked at intermediate distances by lateral branch expansion and exozonal fusion or by broad, short, regularly spaced dissepiments. Linkages aligned transversely or obliquely to branches; each row of linkages and corresponding parts of branches thickened on reverse surface, forming continuous annular, rarely oblique bands that commonly project into the cone as distally deflected keels. Fenestrules fairly large, elongate, oval. High keel on obverse surface of branches; granular core of keel apically bifurcated into two symmetrical or asymmetrical, divergent sheets, to form apical lath. Laminar skeleton on keel thickened apically and extending across outer side of lath. Keels not connected to one another, or with sparse to common lateral, bridge-shaped connections above points of connection between underlying branches. Autozooecia arranged in two alternating 
rows per branch, axially overlapped; axial wall zigzag to sinuous; intermediate to large, cylindrical to irregularly polygonal, height greater than length or width; chamber size greater adjacent to dissepiments, where width commonly greater than length. Hemisepta and other interior structures lacking. Short, direct to laterally oblique distal tube with diameter slightly smaller than endozonal portion of autozooecia. Peristomes thin. Zooecia apparently monomorphic. Basal, axial and transverse autozooecial walls granular, extremely thin or absent laterally around and near distal tube; autozooecial chambers locally lined by thin inner laminar skeleton. Basal plate flat in branch junctions to strongly concave midway along fenestrules, without longitudinal ridges on reverse side or rarely, with only one developed between branch junctions. Extrazooecial skeleton finely laminate, laminae often obscured, containing abundant, inconspicuous small microstyles. Ancestrula and two or three additional zooecia in contact with substratum. In basal portions of zoaria, vesicles also fill interior conical space, space between obverse laths and branches, and fenestrules.

Description: Zoaria are always conical, narrow to broad, with autozooecial apertures on the outer surface; initially narrow cones are sometimes distally expanded. Broad cones are usually longitudinally pleated. Exceptionally, narrow, almost cylindrical cones show pleats that become subordinate cones, thus forming branched zoaria that reach large (decimeters) size, with each hollow zoarial branch itself being made of an outer, initially perforate wall comprised of zooecia-bearing branches linked by dissepiments. The fundamental, zooecia-bearing branches are linear to sinuous, bifurcating, with intermediate spacing and intermediate to broad width. Linear branches show bimodal width due to intersection with dissepiments. Branches are connected by broad, short, regularly spaced dissepiments or, less frequently, anastomoses that involve the exozone of linked branches. Dissepiments are oval to teardrop-shaped in cross section, with long axis oblique to branch axis, pointing distally towards the inner side of the cone. Linkages are aligned transversely or obliquely to branches across the zoarium; the reverse sides of dissepiments and corresponding parts of branches are thickened, forming continuous annular or oblique prominent bands on the interior surface of the cone. These bands commonly have a sharp distal edge, more elevated over the reverse side of the branches than the blunt proximal end. Fenestrules are medium to large sized, oval, elongate, with long axis about twice the length of short axis. Branches have a high median keel on the obverse surface, with a granular core continuous with the axial wall, and bifurcated in its apex into two divergent sheets that may be symmetrical or asymmetrical in cross section and form the core of an apical lath. The laminar sheath of the keel is thickened around the bifid apex, and forms a transversely concave deposit on the outer surface of the apical lath that becomes convex as a result of astogeny. Keels are commonly separate, but may be connected by sparse to abundant lateral processes linking neighbour laths. These processes are placed above points of connection of branches, but are not skeletally continuous with them. Autozooecia are arranged in two alternating rows per branch, overlapped axially and separated by an axial wall with zigzag to sinuous outline. Autozooecia are intermediate to large, with cylindrical to rounded, irregularly polygonal shape in zoarial tangential sections. Autozooecia adjacent to dissepiments are larger and in zoarial tangential sections tend to be roughly equidimensional, frequently wider than long, whereas those adjacent to fenestrules are smaller and have elongate cross sections. The maximum zooecial dimension is perpendicular to the reverse wall in any case. Zooecial chambers lack hemisepta and other structures. Distal tubes are short, broad, somewhat smaller than endozonal diameter, and vertical to slightly tilted towards fenestrules. Each tube ends at a zooecial aperture that is circular or with eight indentations, appearing flower shaped or stellate, slightly elevated above branch surface by a thin peristome. Despite the periodical variation in chamber size, there is no evident polymorphism. Basal, axial and transverse autozooecial walls are granular; other parts of zooecial chambers lack granular skeleton or it is very thin. A thin interior lining of laminar skeleton may be locally present. The basal plate is flat in branch junctions and continuous across aligned dissepiments or anastomoses, becoming progressively curved and strongly concave midway along fenestrules. The reverse side of the basal plate commonly lacks longitudinal ridges, but may bear one, roughly in axial position, developed between successive dissepiments. Extrazooecial skeleton is widely developed across the zoarium, composed of well defined sets of fine, often obscured laminae, pierced by numerous small microstyles. No macrostyles are developed on reverse surfaces of branches or on top of the keel laths. The basal disc is formed by the ancestrula and two or three additional zooecia in contact with the substratum, and is surrounded by abundant large vesicles of laminar skeleton forming a crust that fixed the colony base to the substratum. The supportive vesicular tissue also fills the interior space at the base of the conical zoarium. Vesicles may occur in the core of dissepiments of linear branched species. During astogeny, secretion of vesicles progresses along the growth direction, lining the obverse surface from fenestrules to keel laths. Multiple-cone and narrow zoaria show a great development of vesicular tissue inside the cones.

Remarks: In some zoaria, vermiform curved tubes of an apparent modular commensal are common on the obverse surface, incorporated within the keel tops, bridging across neighbor laths, and causing an extreme thickening of the laminar skeleton as well as gaps facing terminal apertures of the tubes. Similar structures are found on other Devonian fenestrates, especially across the tops of keels of semicosciniids (Suárez Andrés, 1999; McKinney, 2009).

Geographic and stratigraphical distribution: Central and Western Europe; Prague Basin (Czech Republic), PragianZlíchovian; Eifel (Germany), Upper Emsian-Lower Givetian; Cantabrian Zone (Spain), Emsian-Lower Eifelian.

Species composition: Besides the type species, $B$. winteri, three species have been described: $B$. concentrica (Kräusel, 1956), B. sacculus (McKinney \& Kříž, 1986) and $B$. victrola (McKinney \& Kř́̌ž, 1986). 


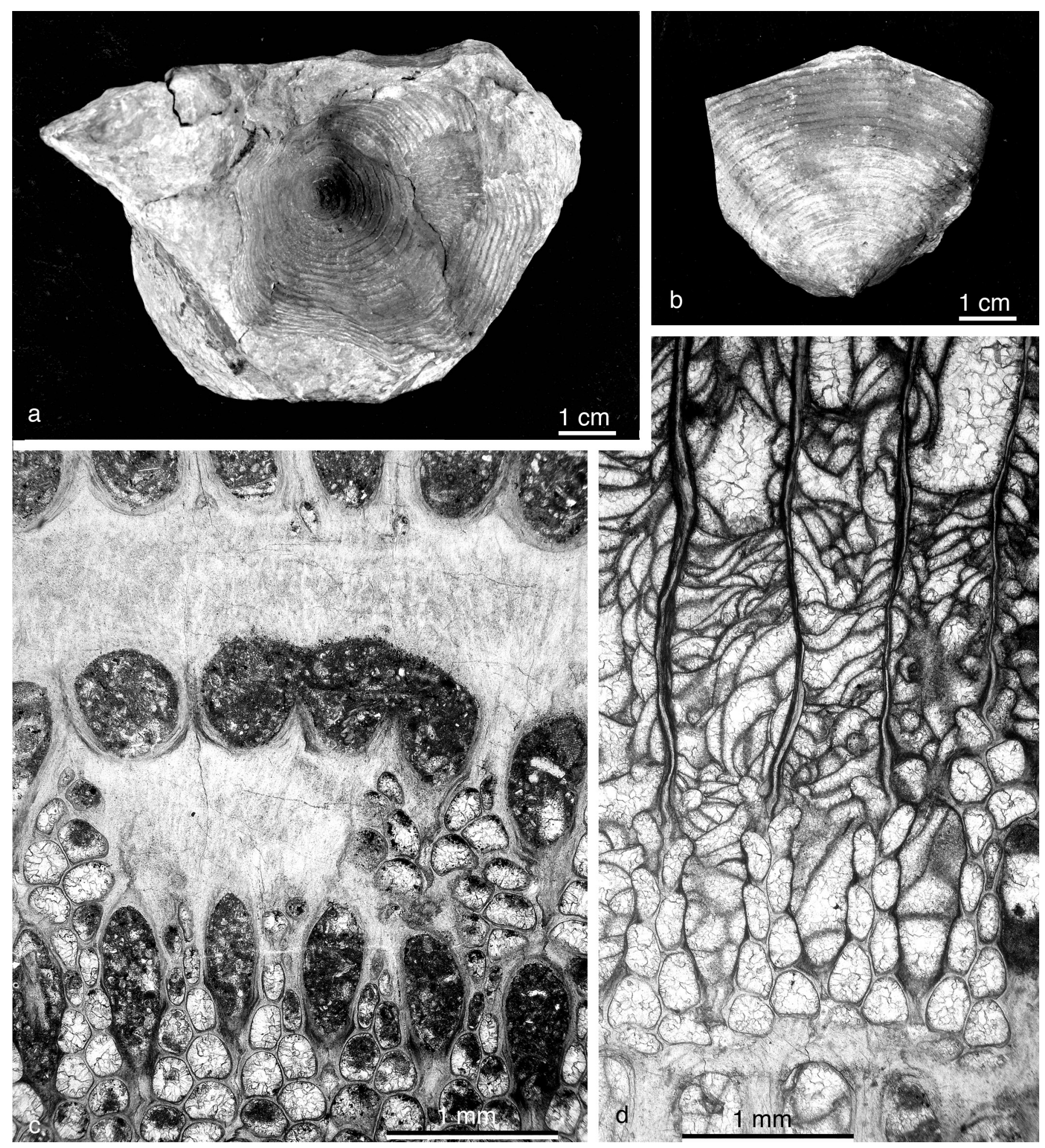

Figure 1. Bigeyina winteri (Bornemann, 1884), Geeser Schichten, Eifelian, Trilobite Fields west of Gees, Eifel region, Rhenish Massif, Germany. a, b, conical zoarium that broke so that a portion of the skeleton adheres to the surrounding sediment (a) and a portion adheres to the sediment-filled core (b), neotype (Kräusel, 1953), SMF XVIII 303a. c, slightly oblique tangential section through endozone of branches in lower half of image and through laminar skeleton of reverse side of branches and thick transverse bands of laminar skeleton that extend into interior of cone, SMF XVIII 307e. d, moderately oblique tangential section through laminar skeleton of reverse sides of branches along lower edge of figure, endozone and obverse exozone near bottom of image, and branch keels in upper half of figure, where cystose skeleton eventually filled the spaces between keels, SMF XVIII $307 f$. 
Bigeyina winteri (Bornemann, 1884) Figures 1-2

1884 Cyclopelta winteri; Bornemann, p. 864-865, P1. 31. 1953 Cyclopelta winteri; Kräusel, p. 45-62, Pls. 1-3., Textfigs. 1-7.

non 1998 Cyclopelta winteri; Suárez, p. 190-192, Pl. 1, figs. 1-3. 2001 Cyclopelta winteri; Morozova, Pl. 20, figs. 3, 4.

Neotype: Senckenberg Forschungsinstitut und Naturmuseum, Frankfurt (SMF) XVIII 303a (Kräusel, 1953).

Description: Zoarium a conical meshwork with a short, narrow base abruptly widening into a long, broadly flaring distal region. Apertures on the outer surface. Branches biserial, straight, connected at regular intervals 2-3 times branch spacing by branch widening and anastomosis due to fusion of exozones of adjacent branches, aligned transversely to growth direction. Reverse side of branch junctions thickened, forming prominent annular bands on inner surface of cone (Fig. 1a, b, c). Annular bands in basal region of zoarium prolonged into interior space of cone to form continuous dome-shaped plates (Fig. 2e).

Fenestrules oval to lance-shaped with proximal end narrower, elongate, length about 2.5 times greater than width. Branches bearing a high median keel between rows of zooecial apertures. Granular core of keel continuous with axial wall, apically broadened and bifurcated into two divergent sheets, roughly symmetrical to asymmetrical, forming a concave lath. Laminar sheath on top of keel lath initially concave, with continued addition of laminar skeleton producing a convex, extremely thickened deposit (Fig. 2a, b, c). Occasional to common transverse arcs connect neighboring keels above dissepiments.

Autozooecia arranged in two partially overlapped rows per branch, apertures offset from side to side of median keel (Fig. 1d). Autozooecia short and deep, erect (Fig. 2e, f), those adjacent to dissepiments different in size and shape from those aside fenestrules. Zooecial chambers at midpoint of fenestrules elongate, narrow, subrounded pentagonal to rectangular in tangential section, with convex base; zooecial chamber size gradually increasing towards branch junctions, where width commonly greater than length and shapes range from hexagonal to pentagonal or irregular, rounded (Fig. 1c, d), with transversely flat base. Axial wall zigzag, with broader amplitude in branch junctions, sometimes almost straight between linkages. In branch regions bordering fenestrules, transverse zooecial walls short and straight, lateral walls flat to slightly concave in branch regions corresponding to fenestrules. In broadened, laterally joined parts of branches, transverse zooecial walls long, linear to strongly proximally concave; lateral walls strongly inflated. Hemisepta absent. Autozooecia sac-shaped, cylindrical to trapezoidal in transverse and longitudinal sections, with long endozone and short distal tube, from half to almost as wide as endozonal region, due to periodical variation in endozonal width (Fig. 2c). Distal tubes roughly vertical, very slightly tilted towards fenestrules, opening to intermediate diameter circular apertures surrounded by low but distinct, fully developed peristomes with stellate terminal structure. Zooecia apparently monomorphic. Basal plate thin, lacking longitudinal ridges on reverse surface, concave at midpoint between branch junctions, becoming flat and continuous along annular bands (Fig. 2c, d).

Extrazooecial laminar skeleton well developed, thickened on top of keel laths and reverse surface of branches and dissepiments. Several dark and clear sets of laminae alternate in extremely thickened deposits. Microstyles abundant, small (Fig. 2d); macrostyles and keel nodes absent. Vesicular tissue profusely developed, sealing inner space of zoarial base, fenestrules and obverse surface from apertures to base of keel laths, progressing along growth direction during astogeny (Fig. 1d). Outer surface of basal region of mature and aged zoaria lined by a solid laminar sheath over keel laths and vesicles (Fig. 2e). Small, cyst-like structures sometimes occur in dissepiment cores, separating endozones of zooecial rows at dissepiment midpoint.

Remarks: Keel laths often show bioimmuration evidence of apparent modular commensal, forming a set of tubes running along and across keel tops; tube walls laminar, integrated into superstructure producing anomalous thickenings, with total thickness of branch cross sections up to $2 \mathrm{~mm}$.

\section{Measurements: Table 1.}

Table 1. Zooecial and zoaria meshwork measurements (in mm) of Bigeyina winteri (Bornemann, 1884) specimens in the SMF from Trilobite Fields, Gees, Eifel region, Germany. AD = aperture diameter; AS = center to center spacing between successive branch anastomoses; BRS = branch spacing; $\mathrm{BW}=$ branch width at base of endozone, mid-fenestrule; $\mathrm{CH}=\mathrm{endozonal}$ chamber height; $\mathrm{CL}=$ endozonal chamber diameter (length) measured parallel with branch axis; $\mathrm{CW}=$ endozonal overall chamber diameter (width) measured perpendicular to branch axis; CWA = endozonal chamber width adjacent to branch anastomosis; $\mathrm{CWF}=$ endozonal chamber width adjacent to middle of fenestrule; $\mathrm{CWI}=$ overall endozonal chamber width between anastomosis and fenestrule center; $\mathrm{FL}=$ fenestrule length; $\mathrm{FW}=$ fenestrule width. $\mathrm{X}=$ mean; $\mathrm{SD}=$ standard deviation; $\mathrm{MIN}=$ minimum value; $\mathrm{MAX}=$ maximum value; $\mathrm{NS}=$ number of specimens measured; $\mathrm{NM}=$ number of measurements.

\begin{tabular}{|l|l|l|l|l|l|l|l|l|l|l|l|l|l|}
\hline & \multicolumn{9}{|c|}{ Zooecial } & \multicolumn{4}{c|}{ Zoarial meshwork } \\
\hline & CL & CH & CW & CWA & CWI & CWF & AD & BW & BRS & AS & FL & FW \\
\hline X & 0.200 & 0.296 & 0.138 & 0.237 & 0.167 & 0.109 & 0.099 & 0.316 & 0.625 & 1.531 & 0.702 & 0.302 \\
\hline SD & 0.023 & 0.32 & 0.064 & 0.034 & 0.037 & 0.024 & 0.011 & 0.061 & 0.084 & 0.251 & 0.102 & 0.051 \\
\hline MIN & 0.161 & 0.220 & 0.083 & 0.170 & 0.131 & 0.083 & 0.076 & 0.245 & 0.481 & 1.149 & 0.056 & 0.228 \\
\hline MAX & 0.264 & 0.347 & 0.305 & 0.305 & 0.244 & 0.158 & 0.115 & 0.47 & 0.843 & 1.920 & 0.851 & 0.388 \\
\hline NS & 2 & 3 & 2 & 2 & 2 & 2 & 2 & 7 & 5 & 3 & 2 & 2 \\
\hline NM & 49 & 28 & 49 & 22 & 12 & 15 & 15 & 39 & 29 & 30 & 11 & 11 \\
\hline
\end{tabular}



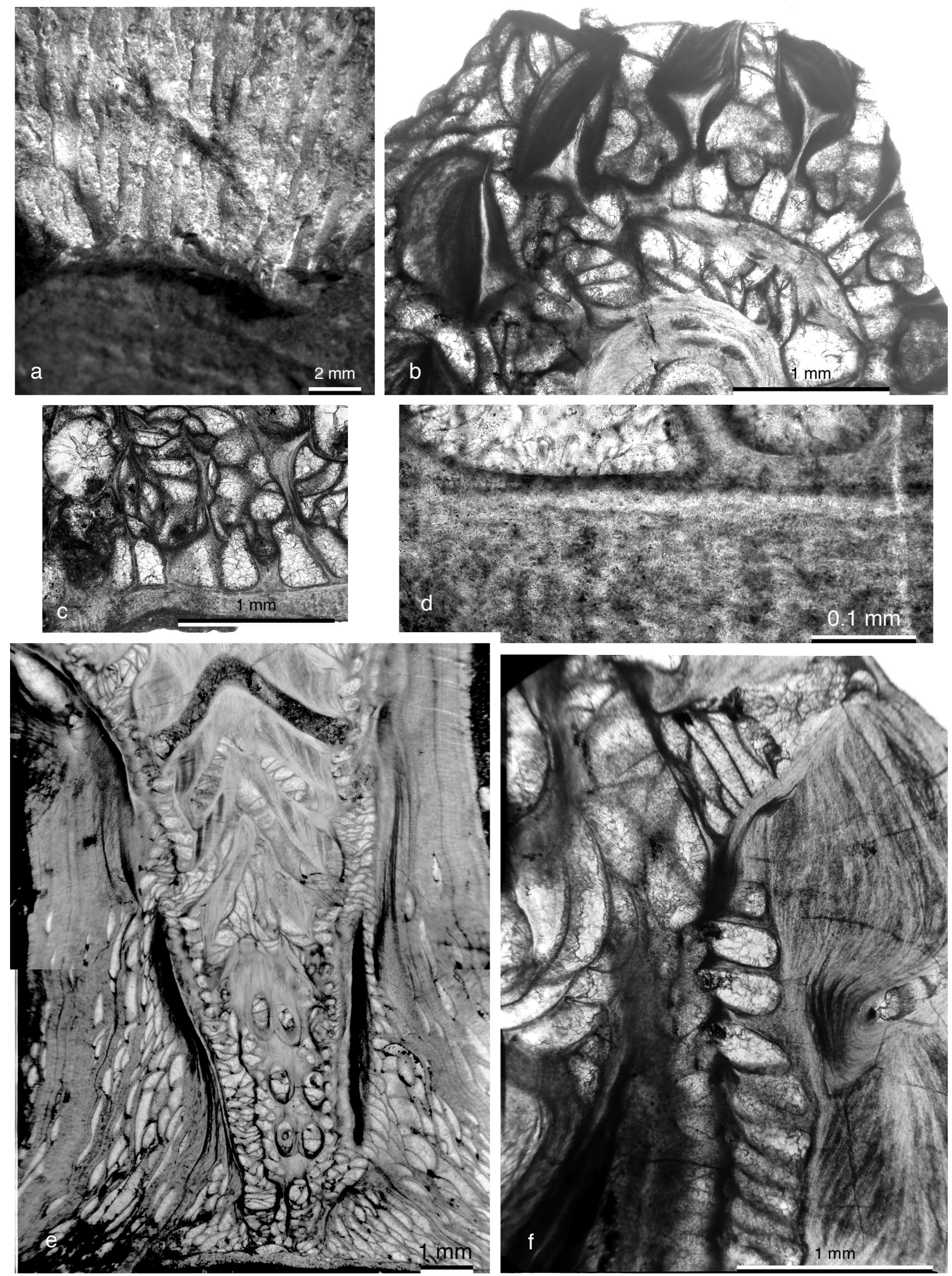


\section{Genus Pseudoisotrypa Prantl, 1932}

\section{Type species: Pseudoisotrypa bohemica Prantl, 1932}

Diagnosis: Zoarium narrow to broadly conical meshwork with autozooecial apertures on outer surface. Branches intermediate to broad, strongly sinuous, spacing intermediate, bifurcating, joined by anastomosis involving endozone; fenestrules elongate, intermediate sized, oval, arranged in rhombic pattern. Branches may be substantially thickened on reverse side, seldom if ever developed into continuous diagonal bands. Reverse thickenings may locally expand into interior of cone as distally curved wave-shaped ridges. High granular-cored keel extending from axial wall along center of obverse side; branch keels not involved in branch anastomosis; granular core of keel divided apically into two divergent sheets to form apical lath; laminar skeleton of keel thickened apically, forming transversely convex deposit with median acuminate crest on outer side of lath; keel laths touching and laterally connected by transverse arcuate processes (without underlying support) over branch anastomoses. Autozooecia of intermediate size, cylindrical to irregularly polygonal, in two alternating rows per branch, overlapped axially; axial wall poorly defined. Maximum autozooecial diameter equals height, perpendicular to reverse wall; autozooecia larger adjacent to anastomosis, where width commonly greater than length; hemisepta and other interior structures absent. Short, intermediate diameter distal tube opening adjacent to obverse keel; peristomes apparently partial. Zooecia apparently monomorphic. Basal, axial and transverse autozooecial walls granular, extremely thin or absent laterally around and near distal tube. Autozooecial chambers locally with laminar interior lining. Basal plate flat, lacking longitudinal ridges on reverse side. Extrazooecial skeleton finely laminate, laminae often obscured, containing abundant large microstyles.

Description: The zoarium is narrow to broadly conical, with autozooecial apertures always on the exterior surface of the cone. The meshwork is made of strongly sinuous, bifurcating branches connected by anastomosis. Branches are intermediate to broad, with intermediate spacing at midpoint of fenestrules. Anastomoses are broad and involve endozones of adjacent autozooecial rows. Fenestrules are oval, elongate, with intermediate size, and occur arranged in rhombic pattern due to branch geometry. Branches may bear thick deposits of laminar skeleton on the reverse surface. These reverse thickenings may be developed along anastomosis into local bands diagonal to branches, elevated above branch surface and inflecting the inner space of the cone, but continuous annular bands do not occur. A complex superstructure is developed on the obverse surface; high keels with granular core extend from axial wall of branches following their sinuous pattern but without being involved in anastomosis. Keel core is apically thickened and bifurcated into two divergent, roughly symmetrical sheets, thus forming the core of an apical lath. The bifurcated core is enveloped by a thick laminar sheath, which shows a low but distinct median acuminate crest on the outer side of the lath. The laths of neighbouring keels touch over anastomosis due to the presence of short, wide transverse linkages, not connected with underlying anastomosis, thus forming a protective structure that resembles the underlying branch meshwork. Autozooecia are cylindrical to polygonal, somewhat irregular in shape and intermediate sized, arranged in two alternating rows per branch. The rows in a branch are slightly overlapped axially, corresponding with the sinuous to zigzag morphology of the axial wall. The maximum autozooecial dimension corresponds with height, perpendicular to the reverse wall. Size, width and length (but not height) vary according to the position of autozooecia; chambers are larger and roughly equidimensional or wider than long where branches anastomose, while length is greater than width in chambers adjacent to fenestrules. Internal structures such as hemisepta are lacking; chambers are connected to the zoarial surface through short, moderate diameter distal tubes, narrower than the endozonal portion of autozooecia, which end at round apertures placed adjacent to the keel and surrounded by apparently partial peristomes. Fully developed peristomes have not been observed. Zooecia are apparently monomorphic. Basal, axial and transverse walls are granular, with an interior laminar lining that is not continuous. The granular skeleton is extremely thin or absent in lateral walls and uppermost parts of zooecial chambers, around distal tubes, and the axial wall is poorly defined. The basal plate is flat all along the branches, and lacks longitudinal ridges on the reverse surface. Extrazooecial skeleton is well developed, often highly

Figure 2. Bigeyina winteri (Bornemann, 1884), Geeser Schichten, Eifelian, Trilobite Fields west of Gees, Eifel region, Rhenish Massif, Germany. a, mold of reverse surface of zoarium preserving impressions of transverse skeletal bands (lower edge of image); obverse keels with broad laths locally preserved in upper two-thirds of image, neotype, SMF XVIII 303a. b, transverse section near base of conical zoarium, through thickened band of skeleton extended to axis of zoarium (center of lower edge of image), ringed successively by a narrow space and branches bearing keels with Y-shaped granular skeleton cores; all original space between basic zoarial elements filled by vesiculose skeleton reaching outer surface of keel laths, SMF XVIII 305c. c, transverse section through three branches, from reverse laminar skeleton, zooecial chambers narrowing upwardly into obverse exozone, to lightly calcified branch keels and intervening vesiculose skeleton, SMF XVIII 307c. d, vague laminations in reverse extrazooecial skeleton of branch, with basal portions of zooecial chambers along upper edge of image, SMF XVIII 307c. e, longitudinal section through axis of encrusting base and lower portion of narrow conical zoarium, with gradually diverging branches encased in vesiculose skeleton that becomes continuous laminar skeleton surrounding the encrusting base and lower portion of the zoarium, University of Bonn (UB) Kr1b. f, small portion of longitudinal section, from reverse side of branch with laminar skeleton extended as thick, distally deflected band into interior of cone (right edge); sac-shaped autozooecia and (lower left) laminar skeletal sheath of branch keel and (upper left) vesiculose skeleton in space between obverse keels, UB Krlb. 
thickened, with obscured sets of fine laminae containing abundant large microstyles. No macrostyles are developed on reverse surfaces of branches or on top of the keel laths.

Geographic and stratigraphical distribution: Prague Basin (Czech Republic); Zlíchovian (Lower Devonian).

Species composition: monospecific.
Pseudoisotrypa bohemica Prantl, 1932

Figures 3-4

1932 Pseudoisotrypa bohemica; Prantl, p. 26-27, P1. 5, figs. 5, 7, 8, ?6, ?9-11.

1932 Pseudoisotrypa cancellata (Počta) (pars); Prantl, Pl. 5, fig. 4 (not figs.12-14, 17).

1986 Cyclopelta bohemica (Prantl); McKinney \& Kříž, p. 4647, Figs. 26B-C, 27A-D.
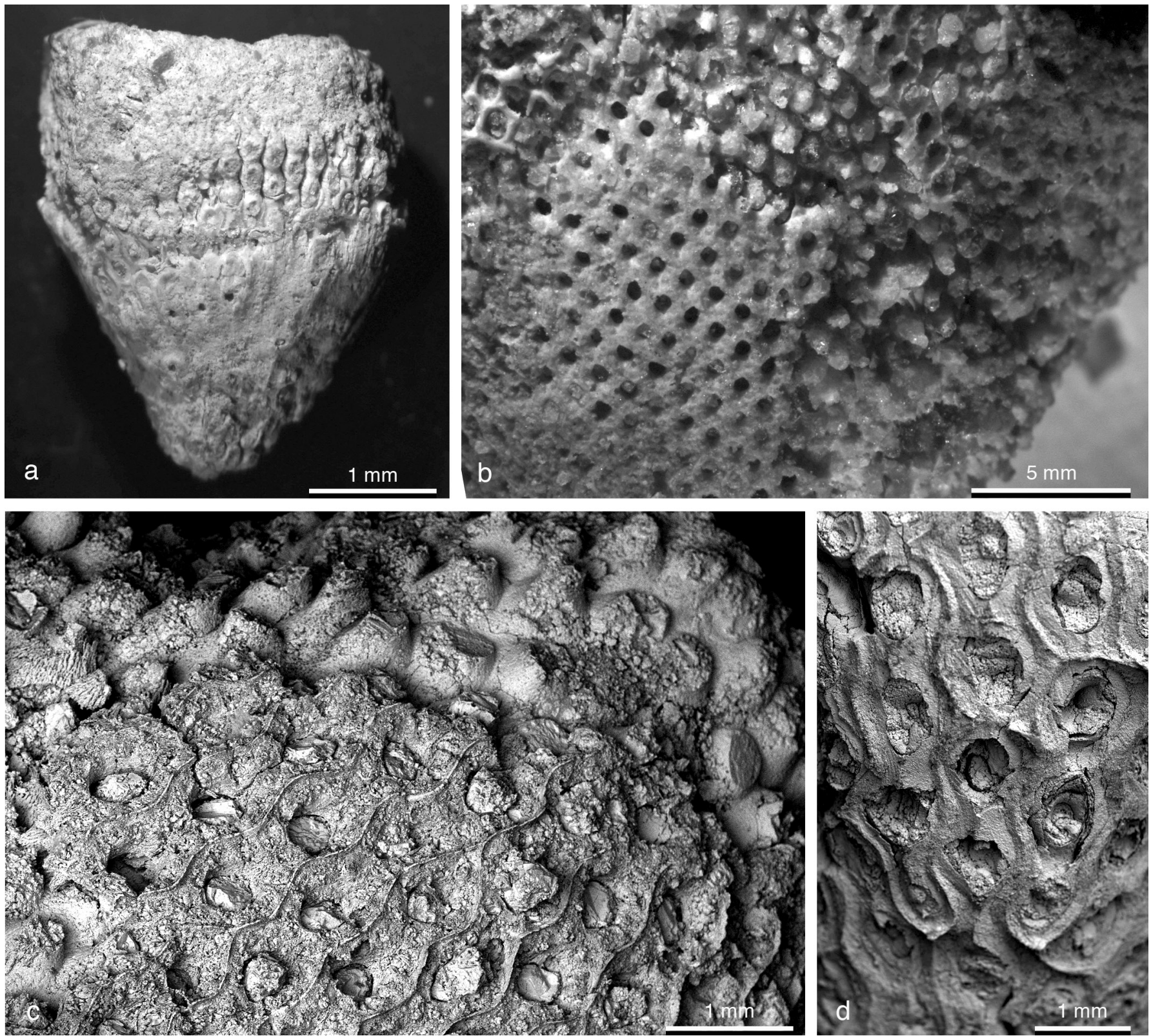

Figure 3. Surface morphology of Pseudoisotrypa bohemica Prantl, 1932, Zlíchov Limestone, Zlíchovian, Devonian, Kaplička, Prague Basin, Czech Republic. a, conical colony with superstructure of branch keel summits and linking bars preserved as molds in upper part of specimen, lectotype (McKinney \& Křriž, 1986), NMCR L15489. b, portion of conical colony preserved as mold of reverse surface of fenestrate meshwork at upper right (note absence of concentric annular thickenings, which would appear as continuous transverse grooves), meshwork of calcareous branches at lower left, and small portion of superstructure remaining at center left margin, NMCR L15488. c, SEM image of obverse surface of fenestrate meshwork with individual branches bearing narrow linear remnants of median keels and in upper right mold of reverse surface where meshwork eroded away, NMCR L15488. d, SEM image of outer surface of superstructure consisting of broad laths along tops of keels, each with an acuminate median crest, and short bars, many with a short transverse median crest, that connect adjacent keel laths, neotype, L15489. 
Description: Zoaria conical, narrow and essentially circular in cross section to moderately widening and longitudinally pleated; obverse surface exterior (Fig. 3a). Branches biserial, sinuous, anastomosed at distances averaging a little less than one and onehalf times branch spacing (Fig. 3b, c). Branches bearing high median obverse keel (approximately one-third to two-thirds mm high to underside of lath) with core of granular calcite, laterally bifurcated into a terminal lath with Y-shaped cross section along outer edge, covered on supporting vertical portion and on undersurfaces of the crest by thin layer of laminar skeleton; on upper surface of "Y" laminar skeleton usually thickened and with convex upper surface with a median acuminate crest; laths laterally broadened over branch anastomoses, with a suture marking contact at midpoint of bridge where laterally projected edges of adjacent laths join and fuse, collectively forming a meshwork that mimics underlying branch meshwork (Fig. 3d; Fig. 4c, d).

Autozooecia offset, alternating from side to side along branches, overlapped axially along a zigzag axial wall (Fig.4a, b). Autozooecia short, erect, inflated, sackshaped, endozonal portion with near-vertical walls (Fig. 4d, e); rounded to subrounded in zoarial tangential sections through endozone; cross sectional shape slightly elongate with gently concave lateral sides between branch anastomoses grading to slightly larger, essentially circular cross sections at branch anastomosis. Distal tube short, close to median keel, erect or slightly tilted disto-laterally, peristome apparently restricted to edge bordering fenestrule. Basal plate about 0.01-0.02 mm thick, lacking longitudinal ridges on reverse surface, gently arcshaped to flat in cross section (Fig. 4d).

Extrazooecial laminar skeleton thinly developed on obverse branch surface and keel sides, thickly developed on upper surface of keel lath, locally very thickly developed (up to $1 \mathrm{~mm}$ thick) on reverse sides of branches, and may be proliferated into cystose skeleton between branches/superstructure and within the cone in proximal parts of the zoarium (Fig. 4e, f).

Measurements: Table 2.

\section{DISCUSSION}

Members of the fenestrate family Semicosciniidae share a set of zoarial characters that can make their external appearance very similar, and this fact may prevent easy identification of some genera. A discussion follows on the characters that allow for the differentiation of Bigeyina and Pseudoisotrypa as independent taxa. Several zoarial and zooecial characters have been used to compare these genera with Semicoscinium and Loculipora, which are closely related to them; the results are summarized in Table 3 .

\section{Differentiating Bigeyina from Semicoscinium}

There are a number of genera within the family Semicosciniidae that were named in the XIX century and acknowledged as distinct taxa since their definition, even in cases such as Fenestrapora Hall, 1885, which so closely resembles Semicoscinium. This has not been the case for Bigeyina (= Cyclopelta Bornemann, 1884); Bassler (1953) identified it as a junior synonym of Semicoscinium Prout, 1859 while Kräusel (1953) provided an improved diagnosis, description and illustration of the neotype that clearly established the characters that allowed differentiating Bigeyina as an independent genus. Such was the treatment given later by McKinney \& Kř́ž (1986), who identified several Bigeyina species in the Lower Devonian of the Prague Basin. McKinney (2008) provided an updated description and discussion of the type species of Semicoscinium, S. rhomboideum Prout, 1859. Despite the many common features shared by both genera, the characters that separate Bigeyina from Semicoscinium are both zoarial and zooecial, the most immediate feature being the annular bands developed on the reverse surface of zoaria,

Table 2. Zooecial and zoarial meshwork measurements (in $\mathrm{mm}$ ) of Pseudoisotrypa bohemica specimens from Kaplička, Prague Basin, Czech Republic. AD = aperture diameter (from McKinney \& Kř́ž 1986); AS = center to center spacing between successive branch anastomoses; BW = branch width (from McKinney \& Kříž, 1986); CH = endozonal chamber height; $\mathrm{CL}=$ endozonal chamber diameter (length) measured parallel with branch axis; $\mathrm{CW}=$ endozonal overall chamber diameter (width) measured perpendicular to branch axis; $\mathrm{CWA}=$ endozonal chamber width adjacent to branch anastomosis; $\mathrm{CWF}=$ endozonal chamber width adjacent to middle of fenestrule; CWI = overall endozonal chamber width between anastomosis and fenestrule center; $\mathrm{FL}=$ fenestrule length; $\mathrm{FW}=$ fenestrule width. $\mathrm{X}=$ mean; $\mathrm{SD}=$ standard deviation; $\mathrm{MIN}=$ minimum value; $\mathrm{MAX}=$ maximum value; $\mathrm{NS}=$ number of specimens measured; $\mathrm{NM}=$ number of measurements.

\begin{tabular}{|l|l|l|l|l|l|l|l|l|l|l|l|l|}
\hline & \multicolumn{9}{|c}{ Zooecial } & \multicolumn{5}{c|}{ Zoarial meshwork } \\
\hline & CL & CH & CW & CWA & CWI & CWF & AD & BW & AS & FL & FW \\
\hline X & 0.202 & 0.224 & 0.138 & 0.181 & 0.138 & 0.111 & 0.107 & 0.393 & 0.902 & 0.495 & 0.339 \\
\hline SD & 0.024 & 0.043 & 0.035 & 0.027 & 0.015 & 0.019 & 0.016 & 0.060 & 0.088 & 0.090 & 0.031 \\
\hline MIN & 0.144 & 0.185 & 0.086 & 0.130 & 0.120 & 0.086 & 0.081 & 0.266 & 0.727 & 0.395 & 0.267 \\
\hline MAX & 0.251 & 0.294 & 0.232 & 0.232 & 0.173 & 0.158 & 0.120 & 0.524 & 1.067 & 0.703 & 0.379 \\
\hline NS & 3 & 3 & 3 & 3 & 3 & 3 & 7 & 7 & 3 & 3 & 3 \\
\hline NM & 62 & 18 & 62 & 22 & 16 & 24 & 53 & 39 & 24 & 22 & 22 \\
\hline
\end{tabular}


which are limited to this genus. Besides this remarkable modification of dissepiments, Bigeyina shows a keel with a bifurcated granular core and an apical lath that may be transversely concave to convex, while no bifurcation ex- ists in the core of Semicoscinium keels, except perhaps in its type species. Furthermore, the axial wall in Semicoscinium is straight, thus conditioning the quadrangular shape of autozooecia in tangential section; the axial wall
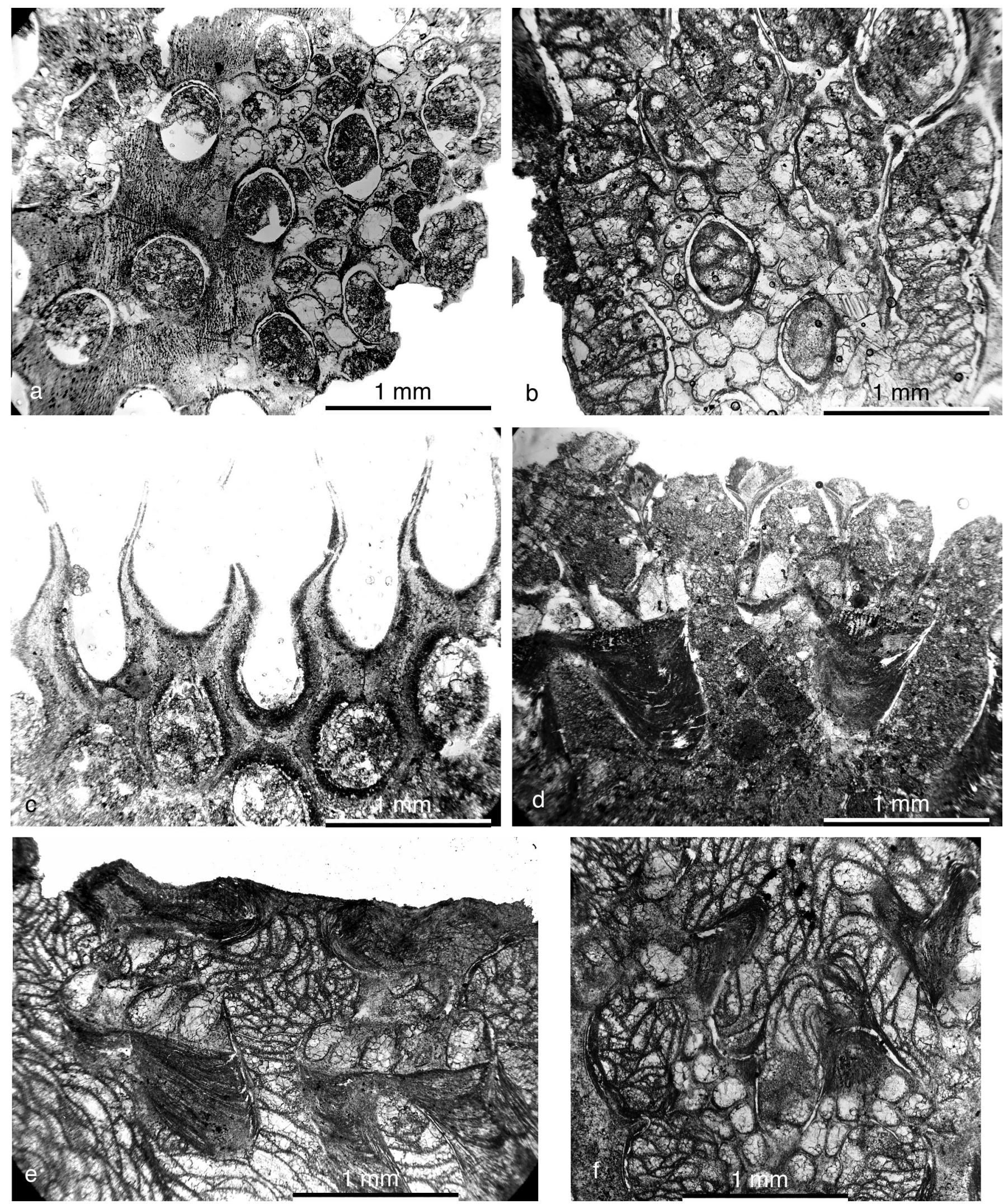
in Bigeyina is zigzag or strongly sinuous, so autozooecia cannot be quadrangular, but cylindrical to polygonal. Only in some parts of branches adjacent to fenestrules the axial wall can be seen to be slightly sinuous, thus forming autozooecia with quadrangular-pentagonal outline. Regarding zooecial characters, all known Bigeyina species lack apparent gynozooecia, which are a remarkable feature of Semicoscinium rhomboideum (see McKinney, 2008). A minor difference is the absence of macrostyles in all described Bigeyina species, in contrast with their presence in some Semicoscinium species. Also, the type species, B. winteri, developed bridges between neighbouring keel laths, unknown in Semicoscinium. With the possible exception of bridges between neighbouring keel laths, none of these characters are likely to have been induced by environmental or other factors than genetic differences, so it can be concluded that Bigeyina is a well defined genus and it is not to be considered a junior synonym of Semicoscinium.

\section{Differentiating Pseudoisotrypa from Bigeyina}

Prantl (1932) reported an interesting fenestrate fauna from the Lower Devonian of the Prague Basin, among which he created a new genus named Pseudoisotrypa, to embrace two species that show certain features that make them different from typical representatives of Isotrypa Hall, 1885. One of these species, $P$. cancellata, was originally defined as Fenestella cancellata and subsequently transferred by Prantl, while the newly created $P$. bohemica was designated as the type species of the new genus. No further reports of Pseudoisotrypa followed Prantl's (1932) descriptions, but the original material of $P$. bohemica and $P$. cancellata was restudied in a revision of the Bohemian fenestrate fauna carried out by McKinney \& Kř́rž (1986), who concluded that $P$. cancellata really belongs to Isotrypa and $P$. bohemica to Cyclopelta (= Bigeyina nom. nov.). Thus, Pseudoisotrypa was considered to be a junior synonym of Cyclopelta Bornemann, 1884 and consequently rejected; the similarities between $P$. bohemica and Bigeyina supported this decision, including particularly the appearance of some sinuous-branched species of Bigeyina described by McKinney \& Kříž (1986).
Despite the many common features shared with Bigeyina, which have been reported above in this paper, we consider that Pseudoisotrypa must be retained as a valid name for a distinct, monospecific genus. The characters that permit the recognition of this genus are mostly zoarial; the superstructure is composed of sinuous keels with a bifurcated granular core, but their apical laths are periodically connected to neighbor keels by transverse linkages bridging over each branch anastomosis, seen over some individual dissepiments in linear-branched species of Bigeyina, and absent in sinuous ones. A very distinctive character is the presence of a low median crest on top of the convex laminar deposit that envelopes the outer surface of the keel lath in Pseudoisotrypa. The reverse surface of Pseudoisotrypa zoaria may show discontinuous oblique bands along anastomosis, but does not fully display the characteristic annular processes developed on the reverse due to thickening of dissepiments aligned transverse to the branches; this feature is exclusive for the genus Bigeyina, and has been consistently described and figured since the first diagnosis by Bornemann (1884). Furthermore, branches in Pseudoisotrypa are strongly sinuous and connected by strict anastomosis that involves endozonal walls of neighbouring branches, and the basal plate is flat along free and anastomosis-linked parts of branches, in contrast with the complex geometry of the basal plate in Bigeyina.

\section{Differentiating Pseudoisotrypa from Loculipora}

Loculipora Hall, 1885 is a semicosciniid genus first described in the USA and later found also in Central and Eastern Europe. Its overall appearance is most similar to that of Pseudoisotrypa, and differentiation of both genera relies on microstructure and superstructure. As it has been described above, the keel laths of Pseudoisotrypa are regularly connected by bridges placed above anastomoses; the superstructure of Loculipora also mimics the primary meshwork below, but it is supported by an underlying continuous network of keels that extend not only along obverse branch midlines but also as skeletal walls grown from and across anastomoses. Transverse sections of branches show differences in two important features:

Figure 4. Thin section morphology of Pseudoisotrypa bohemica Prantl, 1932, Zlíchov Limestone, Zlíchovian, Devonian, Kaplička, Prague Basin, Czech Republic. a, deep tangential section through laminated skeleton of reverse side (left) and zooecial chambers in the deep endozone (right), NMCR L40797. b, tangential section through zooecial chambers in the intermediate to shallow endozone (most of figure), zooecial distal tubes in the exozone (upper right), and lower part of obverse keels (upper right corner), NMCR L24659. c, tangential section through laths at top of keels (bottom) and the median crests of laths (top), NMCR L40798. d, transverse section through two branches and parts of two others, from keel laths (top), lower narrow parts of keels, zooecia, and very thick laminar skeleton of reverse side of branches (bottom), NMCR L24659. e, longitudinal section (growth direction toward right) near base of conical colony through keel laths (top), branch endozone (middle), regions of thickened reverse-side laminar skeleton (bottom), and vesiculose skeleton filling all spaces between, NMCR L18576. f, oblique deep tangential section near base of colony through branch endozones (bottom), thickened reverse-side laminar skeleton (center), to interior of conical colony (top), and vesiculose skeleton filling all spaces in between, NMCR L18576. 
Table 3. Comparison of several diagnostic characters for differentiation of Bigeyina, Pseudoisotrypa, Semicoscinium and Loculipora.

\begin{tabular}{|c|c|c|c|c|}
\hline DIAGNOSTIC CHARACTERS & Bigeyina & Pseudoisotrypa & Semicoscinium & Loculipora \\
\hline Zoarium Cone-/Fan-shaped & $\mathrm{C}$ & $\mathrm{C}$ & $\mathrm{C} / \mathrm{F}$ & $\mathrm{C}$ \\
\hline Branches Linear/Sinuous & $\mathrm{L} / \mathrm{S}$ & $\mathrm{S}$ & $\mathrm{L} / \mathrm{S}$ & $\mathrm{S}$ \\
\hline Keel core bifurcated Yes/No & $\mathrm{Y}$ & $\mathrm{Y}$ & $\mathrm{N} / \mathrm{Y} ?^{1}$ & $\mathrm{~N}$ \\
\hline Keel tops connected Yes/No & $\mathrm{Y} / \mathrm{N}$ & Y & $\mathrm{N}$ & Y \\
\hline Keel links continuous with branch connections Yes/No & $\mathrm{N}$ & $\mathrm{N}$ & - & $\mathrm{Y}$ \\
\hline Branch connections transversely aligned Yes/No & $\mathrm{Y} / \mathrm{N}$ & $\mathrm{N}$ & $\mathrm{N}$ & $\mathrm{N}$ \\
\hline Connections form reverse annular or oblique bands Yes/No & $\mathrm{Y}$ & $\mathrm{N}$ & $\mathrm{N}$ & $\mathrm{N}$ \\
\hline Axial wall Straight/Zigzag & $\mathrm{Z}$ & $\mathrm{Z}$ & $\mathrm{S}$ & $\mathrm{Z}$ \\
\hline Endozonal zooecial chamber Tall/Recumbent & $\mathrm{T}$ & $\mathrm{T}$ & $\mathrm{T} / \mathrm{R}$ & $\mathrm{T}$ \\
\hline Keel nodes Present/Absent & A & A & $\mathrm{P} / \mathrm{A}^{2}$ & A \\
\hline Reverse macrostyles Present/Absent & A & A & $\mathrm{P} / \mathrm{A}^{2}$ & A \\
\hline Basal plate strongly concave between branch links Yes/No & $\mathrm{Y}$ & $\mathrm{N}$ & $\mathrm{N}$ & $\mathrm{N}$ \\
\hline Gynozooecia with strongly ballooned obverse surface Yes/No & $\mathrm{N}$ & $?$ & $\mathrm{Y}$ & $\mathrm{N}$ \\
\hline
\end{tabular}

${ }^{1}$ Possibly bifurcated in the type species

${ }^{2}$ Absent in the type species

the morphology of keel cores and of basal plates. An apically bifurcated granular core of keels can be observed in Pseudoisotrypa, while keel cores of Loculipora consist of a single, undivided skeletal sheet. Pseudoisotrypa has a distinctive basal plate, flattened and lacking reverse ridges, in contrast with the gently curved basal plate of Loculipora, which bears a reduced number of low ridges.

\section{Bigeyina WITH A RARE FENESTRATE GROWTH HABIT}

The Order Fenestrata embraces a broad group of Paleozoic unilaminar bryozoans which consistently built erect zoaria, either cone-shaped, fan-shaped or pinnate. There is a wide range of morphologies, but only one known exception to the erect growth habit, the rare encrusting genus Schischcatella Waschurova, 1964. Cone-shaped zoaria can bear autozooecial apertures on either the inner or the outer surface, and the angle of cone from base to aperture shows a continuous range from little more than $0^{\circ}$ to nearly $180^{\circ}$. Conical zoaria with a progressively increasing angle of aperture towards the distal region are common, and mature colonies with broad angles usually bear longitudinal pleats that increase the effective surface. These pleats can give rise to broadly flaring zoaria with complex, convolute surfaces, still fitting the simple cone model.

Unidentified species of Bigeyina from Lower-Middle Devonian of Asturias (NW Spain) have been found to develop an apparently unique fenestrate growth habit, consisting of multiple elongated cones that give rise, by branching, to bush-like zoaria (Fig. 5). Bigeyina has been observed to occur in the Aguión and Moniello Formations,
Upper Emsian to Lower Eifelian age. The most outstanding outcrop is in the locality of Arnao, where an old quarry exposed an inverted section of red marls belonging to the Aguión Formation (Upper Emsian). Detailed situation and stratigraphy is provided by Álvarez-Nava \& Arbizu (1986), and Arbizu et al. (1993), who carried out a paleoecological study in which four communities were differentiated inside the red marls, two of them with fenestrate bryozoans as the main component. These authors designated as the Isotrypa community an association in which "Isotrypa (...) is the most abundant taxon, with narrow, branching conical forms", but no further description of this unusual growth habit was provided. Bush-like Bigeyina are extraordinarily abundant in these beds, and Arbizu et al. (1993) identified them as Isotrypa, due to apparent similarities with this genus. Suárez (1998a, b) reported Bigeyina in a well exposed outcrop of the Upper Emsian-Lower Eifelian Moniello Formation in Arnao, but erroneously identified one of the species as $B$. winteri and left the other one in open nomenclature. Branching zoaria of Bigeyina are less common in the Moniello Formation, where zoaria never reach sizes as large as in the Aguión Formation, and the number of branched cones in a zoarium is lower. Species composition of Bigeyina in the Moniello Formation is currently under revision by this author.

Branching zoaria of Bigeyina show a narrow, cylindrical to slightly conical base, which grows vertically and gets divided into two or more elongated filial cones or cylinders (Fig. 5a, b), some of which diverge at a relatively high angle and appear to be laterally budded if the sibling cone continues growth in roughly the same orientation as the parent cone (Fig. 5b). The number of divisions determines the appearance of the zoarium, ranging from a small 
set of bifurcating cones in which one cone is terminal in every bifurcation, to a large number of long, cylindrical to slightly conical tubes with a bunch or bush-like appearance (Fig. 5c). In every case, mature colonies were characterized by an extreme development of vesicular tissue sealing the inner space of cones and the obverse surface up to the keel laths, progressing from the base towards the distal region, leaving a reduced surface for active autozooids in proportion with the total colony size. Distal edges of terminal cones, still uncoated by vesicular tissue, have sometimes been observed to widen the angle of aperture. The outer surface of aged colonies was lined by a more or
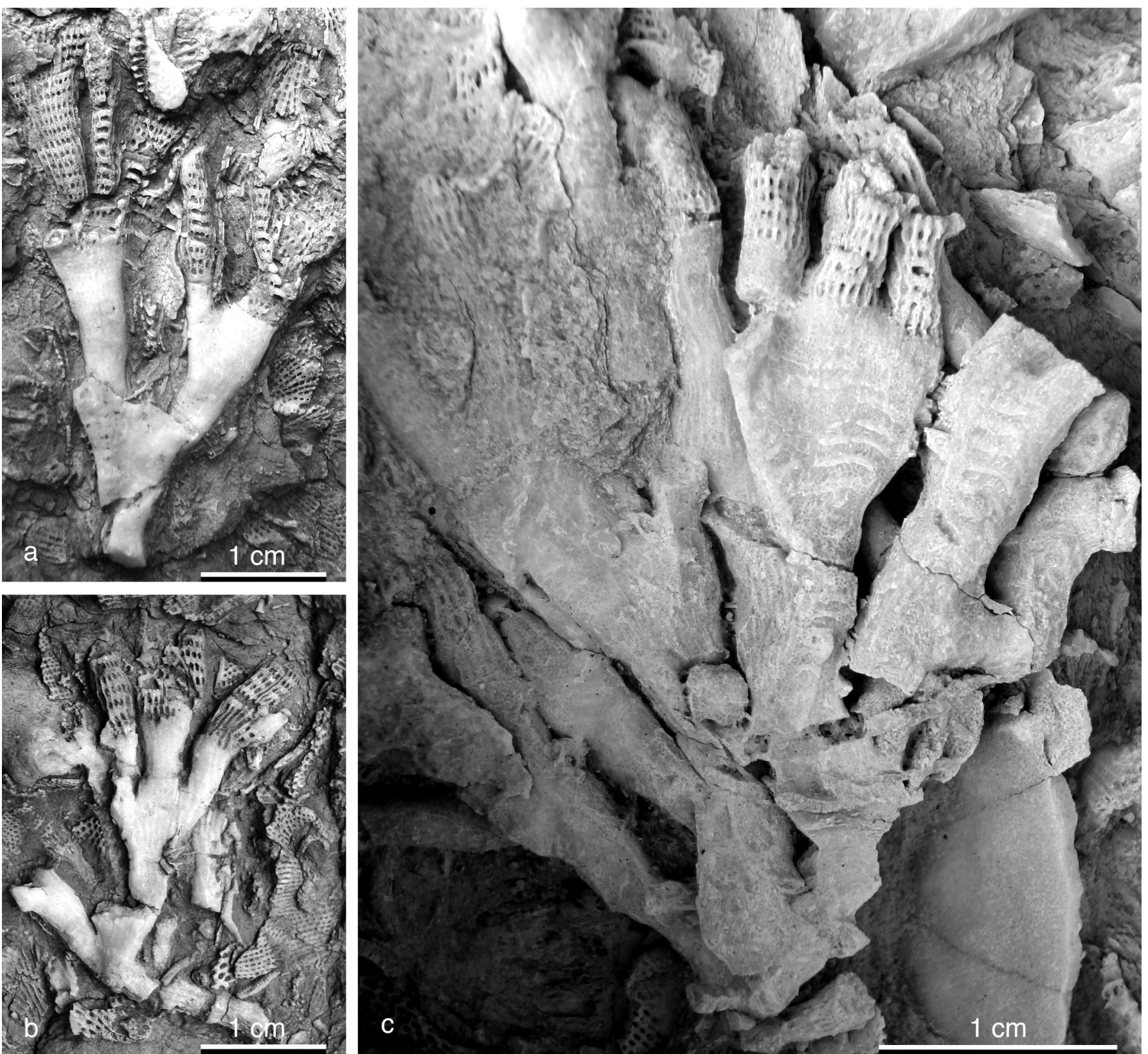

Figure 5. Bigeyina sp. with branching growth habit, Aguión Formation, Emsian, Arnao, Asturias, Cantabrian Zone, Spain. All specimens preserved in the outcrop. a, almost complete zoarium with broken base of attachment, showing narrow, relatively short cones, consistent bifid pattern of cone bifurcation and heavy thickening of proximal region. Transversely aligned dissepiments can be observed in the weathered distal regions of terminal cones. b, large fragment of a zoarium with a cylindrical, stalk-like basal cone; branching morphology is achieved by bifid and threefold division of cones. Sealing tissue covers most of the fragment. c, fragment of a complexly branched, bush-like zoarium developing multiple long, cylindrical branches. The center of the figure shows a flattened cone dividing into three terminal branches. The laminar sheath and keel laths have been weathered and the obverse surface is exposed; some branches have been almost fully eroded, and transverse annular bands can be observed. 
less thick deposit of laminar skeleton over the keel laths and interstitial vesicles; this strengthening layer could grow upwards more than $3 \mathrm{~cm}$ from the colony base.

This branching-like growth habit is apparently extremely uncommon. It has not been previously reported in Bigeyina specimens from other localities, but it has been briefly noted in a Permian polyporid with sparse, coarse, lateral zoarial branches (Condra \& Elias, 1945) and observed in Devonian Fenestrapora zoaria from Germany (Ernst, pers. comm.). It represents a variation in colony shape unusually different for fenestrates, a group with a reduced phenotypical plasticity. The possible functional advantages of this growth form versus simple cones are not clear. Conical and branching colonies of Bigeyina apparently coexisted in the red beds of the Aguión Formation in Arnao; many large, tall complex bush-like zoaria are found in limy to clayey marls, along with conical zoaria that usually show smaller sizes and larger angles of cone expansion. The clayey sediments and the preservation of large, complete zoaria would indicate a low energy environment with dead, fallen colonies becoming an available substrate for the new ones. A different pattern can be seen in the Moniello Formation. Branching Bigeyina are found in marly bioclastic limestones with wakestone to packstone texture interbedded with crinoidal limestones; here zoaria consist of a reduced number of bifurcating cones, and their size tends to be smaller than that of zoaria found in muddy rocks of the Aguión Formation. Quiet water, bryozoan-rich beds of the Moniello Formation in Arnao with mudstone and wackestone texture yield very few branching zoaria, and flaring conical Bigeyina are common instead.

Variations in size and number of cones seem to be at least in part related to environmental factors. Colonies inhabiting low energy areas may have lived longer, thus reaching larger sizes than those of colonies subject to strong currents. Besides, the adequate height of a conical colony to take advance of passive flow is larger in quiet waters. Flume experiments and field observation carried out by Balsam \& Vogel (1973) allowed the authors to conclude that archeocyatids developed narrow, tall cones in quiet environments while those under stronger currents effectively exploited passive flow with shorter, broader morphologies. This hypothesis may explain the observed differences in size, but is not satisfactory for the development of the branching habit itself. Young colonies may have used passive flow for filtering prior to bifurcation, but increasing number of cones would cause some "shadow" zones to occur, as branching cones are not contained in a single plane, thus reducing efficiency of this process. On the other hand, the limited stratigraphical and geographical extension of this peculiar growth habit may indicate that it was an abnormal character locally developed by this genus, which possibly was not competitive with conventional single-cone morphology.
The outcrop of the Aguión Formation at Arnao is well known as a part of a coastal exposure of Devonian rocks with a diverse paleontological content, (Arbizu \& MéndezBedia, 2006), including reefal fauna forming build-ups and biostromes, which is currently evaluated for the exhibition and preservation of its extraordinary geological heritage. The common presence of Bigeyina with well preserved zoaria and the occurrence of this unusual branching habit provide more arguments to support the need for preservation of one of the most representative examples of the Devonian reefal facies of the Cantabrian Zone.

\section{CONCLUSIONS}

The fenestrate bryozoan name Cyclopelta Bornemann, 1884 is a homonym of the insect Cyclopelta Amyot \& Serville, 1843 . The homonym is substituted herein by the new name Bigeyina.

The bryozoan family Semicosciniidae explored an increase in diversity during Devonian times, when a number of genera arose developing exclusive features, mainly consisting of more or less complex superstructures. Many members of this family share zoarial features with subtle variations, a fact that has troubled clear recognition of some taxa. This is the case of Bigeyina and Pseudoisotrypa. The study reported herein leads to the conclusion that they are closely related but independent taxa, with differentiation relying on superstructure, dissepiment and autozooecial morphology as well as microstructure. The development of prominent, zoarium-wide annular or oblique bands on the reverse surface due to thickening of linkages is the most conspicuous character that allows for the recognition of Bigeyina.

A revision of the respective type species, $B$. winteri and $P$. bohemica, has been carried out, and diagnosis and descriptions of both genera and type species are provided. The known geographic and stratigraphic distribution of Bigeyina and Pseudoisotrypa is limited, especially so for the latter, which is monospecific and endemic of the Prague Basin. The genus Bigeyina embraces four described species from Germany and the Czech Republic and it has been reported from NW Spain, where it shows some peculiar features and its species composition is currently under study.

A rare growth habit has been observed in Bigeyina specimens from Devonian Aguión and Moniello Formations outcropping in Arnao, NW Spain. It consists of a set of more or less numerous long, narrow, bifurcating cones forming zoaria with a branched appearance. This highly anomalous morphology has not previously been reported elsewhere for this genus. Branched colonies seem to have coexisted with common, conical Bigeyina in Arnao and many large, complex, almost complete zoaria occur in the red marls of Aguión Formation. The paleoecological sig- 
nificance of this rare morphology remains unknown, but regarding its reduced geographical and stratigraphical distribution, it may have been an aberrant growth mode that was not successful in competition with conventional fenestrate morphologies. This finding comes to support the need for preservation of the classical outcrop of Arnao, which is being evaluated for the protection of its geological heritage.

\section{ACKNOWLEDGEMENTS}

The authors wish to express their gratefulness to Andrej Ernst and Kamil Zagorsek, for providing photographs of Bigeyina winteri and Pseudoisotrypa bohemica, respectively. J. L. Suárez is also grateful to María L. Martínez-Chacón, Isabel Méndez-Bedia and Francisco Soto for helpful discussion, and Miguel Arbizu, main researcher of the project "Itinerario Geológico-Paleontológico de la Plataforma y Arrecife de Arnao", for making possible the first approach to a bryozoan inventory of the Arnao outcrop. The reviewers Andrej Ernst and Francisco Soto are also thanked for their valuable suggestions.

\section{REFERENCES}

Álvarez-Nava, H. \& Arbizu, M. 1986. Composición y desarrollo de un arrecife emsiense en la plataforma de Arnao (Asturias, NO de España). Memorias I Jornadas de la Sociedad Española de Paleontología, Universidad de Zaragoza, 33-51.

Amyot, C.-J.-B. \& Serville, A. 1843. Histoire Naturelle des Insectes. Hémiptères. Libraire Encyclopédique de Roret, Paris, $675 \mathrm{pp}$.

Arbizu, M. \& Méndez-Bedia, I. 2006. El Patrimonio Natural y Cultural de Castrillón (Asturias): Geología, fósiles e historia minera. Trabajos de Geología, 26, 73-91.

Arbizu, M., Álvarez-Nava, H., Méndez-Bedia, I. \& GarcíaLópez, S. 1993. Las comunidades bióticas de las "Capas con Trybliocrinus" (Devónico Inferior) en la Plataforma de Arnao (Asturias, Noroeste de España). Revista Española de Paleontología, $\mathbf{n}^{\mathbf{0}}$ extraordinario, 71-77.

Balsam, W. L. \& Vogel, S. 1973. Water movement in archaeocyathids: evidence and implications of passive flow in models. Journal of Paleontology, 47, 979-984.

Bassler, R. S. 1953. Bryozoa. In: Treatise on Invertebrate Paleontology, Part G (ed. R. C. Moore). Geological Society of America \& University of Kansas Press, 253 pp.

Borg, F. 1926. Studies on recent cyclostomatous Bryozoa. Zoologiska Bidrag från Uppsala, 10, 181-507.

Bornemann, J. G. 1884. Cyclopelta winteri, eine Bryozoe aus dem Eifeler Mitteldevon. Zeitschrift der Deutschen Geologischen Gesellschaft, 36, 864-865.

Condra, G. E. \& Elias, M. K. 1945. Bicorbula, a new Permian bryozoan, probably a bryozoan-algal consortium. Journal of Paleontology, 19, 116-125.

Ehremberg, C. G. 1831. Symbolae Physicae, seu icones et descriptiones corporum naturalium novorum aut minus cognitorum, quae ex itineribus per Libyam, Aegyptum, Nubiam, Dongalam, Syriam, Arabiam et Habessiniam studio annis 1820-25 redierunt. Pars Zoologica: v. 4, Animalia Evertebrata exclusis Insectis.

Elias, M. K. \& Condra, G. E. 1957. Fenestella from the Permian of West Texas. Geological Society of America Memoir, 70, $158 \mathrm{pp}$.

Hall, J. 1885. On the mode of growth and relations of the Fenestellidae. Report of the State Geologist of New York for the year 1884, 35-46.

Kräusel, W. 1953. Cyclopelta winteri (Bryozoa) aus dem Mittel-Devon der Eifel. Senckenbergiana, 34, 43-52.

Kräusel, W. 1954. Cyclopelta aus der corbis-Bank des Oberharzer Mittel-Devons. (Bryoz.). Senckenbergiana, 34, 246.

Kräusel, W. 1956. Bryozoen-Arten F. A. Romer's (Fenestellidae) aus dem deutschen Devon. Senckenbergiana, 37, 59-64.

McKinney, F. K. 2008. Taxonomic notes on Semicoscinium Prout and other $19^{\text {th }}$ Century Fenestrate Bryozoa from the USA. In: Bryozoan Studies 2007: Proceedings of the 14th International Bryozoology Association Conference, Boone, North Carolina, July 1-8, 2007 (eds. S. J. Hageman, M. M. J. Key Jr. \& J. E. Winston). Virginia Museum of Natural History, Special Publication, $\mathrm{n}^{\circ}$ 15, 133-141.

McKinney, F. K. 2009. Bryozoan-hydroid symbiosis and a new ichnogenus, Caupokeras. Ichnos, 16, 193-201.

McKinney, F. K. \& Kř́žz, J. 1986. Lower Devonian Fenestrata (Bryozoa) of the Prague Basin, Barrandian Area, Bohemia, Czechoslovakia. Fieldiana Geology, n. s. 15, 90 pp.

Morozova, I. P. 1987. Morfogenez, sistema i colonial'naya integratsiya mshanok otryada Fenestrida. In: Morfogenez i puti razvitiya kolonial'nosti mshanok $i$ kishechnopolost$n y k h$. Trudy Paleontologicheskogo Instituta Akademiya Nauk SSSR, 222, 70-88 [in Russian].

Morozova, I. P. 2001. Mshanki otryada Fenestellida. Trudy Paleontologicheskogo Instituta, Rossiiskaya Akademiya Nauk, Osnovany, 277, 176 pp. [in Russian].

Prantl, F. 1932. Revise Ceských devonských fenestellid. Palaeontographica Bohemiae, 15, 70 pp.

Prout, H. A. 1859. Third series of descriptions of Bryozoa from the Palaeozoic rocks of the western states and territories. Transactions of the Academy of Sciences of St. Louis, 1, 443-452.

Shulga-Nesterenko, M. I., Nekhoroshev, V.P., Morozova, I. P., Astrova, G. G. \& Shishova, N. A. 1960. Order Cryptostomata. In: Osnovy paleontologii, spravochnik dlya paleontologov i geologov SSSR (ed. T. G. Sarycheva). Izdatelstvo Akademii Nauk SSSR, Moscow, 7, $72-93$ [in Russian].

Suárez Andrés, J. L. 1997. Briozoos Fenestrados de la Formación Moniello (Devónico Inferior y Medio, Asturias). Primeros datos. In: Libro de resúmenes y excursiones de las XIII Jornadas de Paleontología y V Reunión Internacional Proyecto 351 PICG (eds. A. Grandal D'Anglade, J. C. Gutiérrez-Marco \& L. Santos Fidalgo). Universidade da Coruña, La Coruña, 247-250.

Suárez Andrés, J. L. 1998a. Briozoos Fenestrados de la Formación Moniello (Devónico) en el área de Arnao (Asturias, España) I: Fenestellidae. Revista Española de Paleontología, 13, 187-196. 
Suárez Andrés, J. L. 1998b. Briozoos de la Formación Moniello (Devónico, Asturias). Seminario de Investigación, Departamento de Geología, Universidad de Oviedo, 46 pp. (Unpublished).

Suárez Andrés, J. L. 1999. Parasitismo en briozoos del Devónico de la Zona Cantábrica. Temas Geológico-Mineros, 26, ITGE, 647-650.
Waschurova, L. I. 1964. Mshanki iz nidjnedevonskij otlodjenii Zeravshanskogo i Turkestanskogo jrebtov. Trudy Uprableniya Geologii i Ojrany Nedr pri Sovete Ministrov Tadjikskoi SSR Paleontologiya i Stratigrafiya, 1, 75-166 [in Russian].

Manuscrito recibido: 14 de Junio, 2010 Manuscrito aceptado: 8 de Noviembre, 2010 